\title{
School Surveillance: Primary AND SECONDARY
}

\section{SCHOOLS}

Primary and secondary schools have long engaged in surveillance practices. These include physical observation, attendance registers, classroom arrangement, uniforms, assessments and exams, and publishing of rankings or league tables. In recent years, with advancements in surveillance technologies, some primary and secondary schools have expanded their use of technology to surveil students. For example, some secondary and primary schools have introduced closed-circuit television cameras (CCTV), metal detectors, face and fingerprint recognition technology, chipped identity cards, electronic registers, cyberspace surveillance, and even electronic systems to log students' lunch choices so that parents can check their child's diet. Although reasons of health and personal safety (e.g., the reduction of bullying, theft, smoking, junk food consumption, and truancy) are sometimes cited, in general the implementation of surveillance devices tends to be justified on grounds of security,

Fears of violent incidents such as the stabbing of head teacher Phillip Lawrence in London in 1995 and the massacre in a Primary School in Dunblane, Scotland in 1996 in which an outsider shot and killed 16 children and their teacher, and school shootings in the United States such as at Columbine High School in 1999and Sandy Hook Elementary School in 2012, have provided the impetus for the introduction of new surveillance technologies.

Some argue that teachers need protection from violent young people and need assistance with searching students for weapons, drugs, and alcohol. A 2010 study conducted in Scotland by Black and colleagues suggests that the presence of a police 
officer tends to improve feelings of security. However, there is evidence to suggest that surveillance systems do not ensure security—-for instance, Columbine High School had a video surveillance system and an armed guard assigned to the school. There have also been reports of physical abuse from school police officers and students being arrested for noncriminal offenses such as being late or wearing the "wrong" clothes.

Some scholars have suggested other interconnected reasons for the use of surveillance in schools. These include a culture of fear, commercial gain for security device businesses, a wider culture of control of socially and economically disadvantaged young people, the wider securitization of societies that is pervading both private and public spaces, and the counterterrorism agenda.

Others argue that the devices are perceived differently according to social group. In a 2010 project on the "surveilled," Mike McCahill and Rachel Finn examined the social impact of new surveillance technologies on the lives of 13- to 16-year-old children in the United Kingdom. The researchers examined three schools and found that young people of lower socioeconomic classes were more likely to feel they were the target of surveillance, and were more likely than middle-class young people to adjust their behavior when they felt watched, including staying away from spaces under surveillance. Middle-class young people did not tend to feel they were the target of surveillance; rather, they felt that surveillance devices were installed for their own security. In addition, females were more uncomfortable with surveillance than males.

According to Emmeline Taylor, there is a lack of legal regulation around surveillance in schools. UK and U.S. legislation provides little protection for young people in school settings when it comes to surveillance. However, resistance to new technologies of school surveillance has occurred. For instance, in 2009, pupils at an East London school walked out in protest after CCTV cameras were installed in their 
classrooms without consultation, claiming their civil liberties had been infringed.

There is still a lot that is not known about the impact of surveillance technologies in primary and secondary schools. For example, there is as yet, a lack of research mapping the surveillance devices in schools, even though some have argued that they have been unevenly installed. There is also virtually no data on what is done with the CCTV tapes, who watches them, or whether they are watched at all.

Charlotte Chadderton

See also Closed-Circuit Television; Fear, Culture of; School Surveillance: Colleges and Universities; Surveillance, Culture of;

\section{FURTHER READINGS}

Big Brother Watch (2014) Teachers hit back at 'permanent surveillance' in the classroom. $\quad$ https://www.bigbrotherwatch.org.uk/2014/04/teachers-hit-backpermanent-surveillance-classroom/

Black, C. Homes, A. Diffley, M. Sewel, K. and Chamberlain, V. (2010) Evaluation of campus police officers in Scottish schools. Ipsos MORI Scotland.

Casella, R. (2010) Safety or social control? The security fortification of schools in a capitalist society. In Monahan, T. and Torres, R. D. (eds.) Schools under surveillance. Cultures of control in public education. New Brunswick, New Jersey, and London: Rutgers University Press, pp. 73-86.

Chadderton, C. (2013) Secondary schools under surveillance: young people 'as' risk in the UK. An exploration of the neoliberal shift from compassion to repression. In Cudworth, E.; Senker, P. and Walker, K. (eds.) Technology, Society and Inequality: New Horizons and Contested Futures, Peter Lang, 139-154. 
Furedi, F. (2005) Politics of fear. London: Bloomsbury academic.

Giroux, H. A. (2009) Youth in a suspect society. Democracy or disposability? New York: Palgrave Macmillan.

Harris, J. (2011) School surveillance: how big brother spies on pupils $\quad$ http://www.theguardian.com/uk/2011/jun/09/schools-surveillancespying-on-pupils

Hope, A. (2005) Panopticism, play and the resistance of surveillance: case studies of the observation of student internet use in UK schools. British Journal of Sociology of Education, 26 (3), pp. 359-373.

Hope, A. (2009). CCTV, school surveillance and social control. British Educational Research Journal, 35(6), pp. 891-907.

Marx, G. and Steeves, V. (2010) From the Beginning: Children as Subjects and Agents of Surveillance. Surveillance \& Society, 7(3/4), pp. 192-230.

McCahill, M. and Finn, R. (2010) The Social impact of Surveillance in Three UK Schools: 'Angels', 'Devils' and 'Teen Mums'. Surveillance \& Society, 7(3/4), pp. 273-289.

Monahan, T. and Torres, R. D. (2010) Introduction. in Monahan, T. \& Torres, R. D. (eds.) Schools under surveillance. Cultures of control in public education. New Brunswick, New Jersey, and London: Rutgers University Press, pp. 1-18.

Simmons, L. (2010) The docile body in school space. In Monahan, T. and Torres, R. D. (eds.) Schools under surveillance. Cultures of control in public education. New Brunswick, New Jersey, and London: Rutgers University Press, pp. 55-72.

Taylor, E. (2013) Surveillance Schools. Security, discipline and control in 
contemporary education. Basingstoke and New York: Palgrave Macmillan.

UK Press Association (2009) School dinners spy website launched. Available from: http://latestnews.virginmedia.com/news/tech/2009/10/08/school dinne rs spy website launched. [Accessed 27/09/09] 